\section{Cover Crop Rotations Alter Soil Microbiology and Reduce Replant Disorders in Strawberry}

\author{
Ann Toren Seigies and Marvin Pritts ${ }^{1}$ \\ Department of Horticulture, 134A Plant Science Building, Cornell \\ University, Ithaca, NY 14853
}

Additional index words. black root rot, fumigation, fungal pathogens, nematodes, Rhizoctonia

Abstract. In July 2001, a study was established in a field with a 30-year history of perennial strawberry production to examine effects on replant disorder of 12 different species of preplant cover crops, soil fumigation (methyl bromide plus chloropicrin), and fallow management. In May 2002, strawberries ('Jewel') were planted into pots containing soils with the incorporated cover crops, grown for 1 year, and then fruited. Strawberry yields in 2003 were highest in pots containing indiangrass (Sorghastrum avenaceum) and brown mustard (Brassica juncea) -incorporated soils, resulting in $\mathbf{3 2 \%}$ and $28 \%$, respectively, higher yield than plants in pots containing untreated, bare fallow soil. Yield was lowest in fumigated soil or soil incorporated with sunnhemp (Crotolaria juncea), having $19 \%$ and $10 \%$ less yield than the fallow treatment, respectively. In Aug. 1999, a complementary study was established in a field with a 7-year history of continuous perennial strawberry production to examine the effects of single species and multiple species rotations on replant disorder, bacterial populations, and fungal pathogens over 2 fruiting years. Cover crop treatments included various monocultures and sequences of perennial alfalfa (Medicago sativa), brown mustard, kale (B. oleracea 'Winterbor'), sweet corn (Zea mays 'Saccharata'), rye (Secale cereale), hairy vetch (Vicia villosa), marigold (Tagetes patula 'Nema-gone'), oats (Avena sativa 'Newdak'), and sudangrass (Sorghum bicolor $\times S$. sudanese). These rotations were compared with the effects of fumigation using methyl bromide with chloropicrin (99:1), continuous strawberry, and bare fallow. Symptoms of replant disorder developed in the continuous strawberry plots within a few months of planting. Plants in the fumigation treatment produced greater fruit yield than all other treatments in $2003,139 \%$ more than plants from the continuous strawberry treatment. Strawberry plants grown in the kale/sweet corn/rye treatment had consistently high yield, and both the hairy vetch/marigold/rye and the oats/sudangrass/rye treatments led to marked improvement over the continuous strawberry treatment. Plants from the brown mustard treatment also were more vigorous and productive than plants from the continuous strawberry treatment during 2002 despite having relatively low foliar biomass and a relatively high level of fungal infection on strawberry plant roots. In the field, symptoms of replant disorder were best overcome by fumigation with methyl bromide or multiple species rotations, particularly that of kale followed by sweet corn and rye. Although Rhizoctonia levels were associated with poor root health, general fungal and bacterial root infection rates were not consistently associated with the presence of visible symptoms of replant disorder nor with strawberry plant growth and productivity.

Many crops experience a decline in productivity when replanted in the same site (Savory, 1966). In strawberry, symptoms of replant disorder are poor productivity, weak root systems, root necrosis, and foliar drying (Fort and Shaw, 2000; Molot and Ferriere, 1989). Multiple cultural practices, and soil and environmental factors, have been associated with replant problems (Aldea et al., 1998; Fehrmann, 1988; Mai et al., 1994; Wing, et al., 1995); also

Received for publication 18 Apr. 2006. Accepted for publication 28 May 2006. We thank Mary Jo Kelly for technical assistance during the study, Skip Jackson at Iron Kettle Farms for accommodating our research, and Laurie Drinkwater and Janice Thies for helpful reviews.

${ }^{1}$ To whom reprint requests should be addressed; e-mailmpp3@cornell.edu.
Cover crop species differ in their ability to reduce symptoms of replant disorder. Elmer and LaMondia (1999) found oats (Avena strigosa 'Saia' Schreb) and sorghum-sudangrass (Sorghum bicolor x S. sudanese 'Triple S') in rotation with strawberry reduced pathogens and nematodes. Marigold has effectively decreased disease occurrence and improved yields in sites replanted to fruit crops (Jagdale et al., 2000; Merwin et al., 2001; Reynolds et al., 2000). Species of Brassica have been shown to reduce the occurrence and severity of replant disorders by decreasing soilborne pathogens while increasing populations of pathogen-suppressing bacteria such as fluorescent pseudomonads (Mazzola et al., 2001; Sances and Ingham, 1997). Not all cover crops are suppressive of pathogens. Elmer and LaMondia (1999) and LaMondia (1999) demonstrated that population densities of soilborne strawberry pathogens were either increased or unchanged by buckwheat (Fagopyrum esculentum Moench), canola (Brassica napus L.), rye (Secale cereale L.), or 'Garry' oats. Differences also exist within cultivars of potentially suppressive cover crops. Mazzola and $\mathrm{Gu}$ (2002) found that wheat cultivars differed in their ability to suppress pathogens associated with apple replant disorder.

Our objectives were to 1) identify potential cover crops to reduce replant disorder in strawberry and 2) describe their effects on microbial populations in the root and rhizosphere. Both pot and field studies were used.

\section{Materials and Methods}

Pot study. A site consisting of a Howard gravelly loam was selected in Candor, N.Y., that had a 30-year history of nearly continuous strawberry production. Strawberry plants in the site were demonstrating poor vigor and possessed roots with lesions. Cover crop species were seeded into the site on 20 July 2001 in plots $3 \mathrm{~m}$ wide by $13 \mathrm{~m}$ long $(0.0026$ ha/plot) 1 wk after the previous strawberry planting was disked. Each treatment was broadcast seeded at about twice normal rates to ensure a dense stand (Table 1). Triticale (Triticum aestivum $\mathrm{x}$ Secale cereale or $\mathrm{x}$ Tritosecale) and brown mustard were seeded $1 \mathrm{~m}$ later when germination temperatures were more optimal for these species. Immediately after sowing, the seedbeds were packed and irrigated. If germination or establishment was low, plots were overseeded to ensure a thick stand. Plots ran perpendicular to original strawberry plant rows.

Cover crops included Japanese millet (Enchinochloa frumentacea), sorghumsudangrass, buckwheat, cowpea (Vigna unguiculata), berseem clover (Trifolium alexandrinum), sunnhemp (Crotolaria juncea), marigold ('Crackerjack'), brown mustard, black-eyed susan (Rudbeckia hirta), indiangrass (Sorgastrum avenaceum), switchgrass (Panicum virgatum), and triticale. Two plots were maintained as bare fallow. These plots were not seeded to cover crops 
Table 1. Plant species, seed source, and seeding date and rate for preplant cover crop treatments used in the pot study.

\begin{tabular}{|c|c|c|c|}
\hline Species & Common Name & Seed Source & $\begin{array}{c}\text { Seeding Rate } \\
\left(\mathrm{kg} \cdot \mathrm{ha}^{-1}\right)\end{array}$ \\
\hline Enchinochloa frumentacea & Japanese millet & Seedway, Penn Yan, N.Y. & 44.8 \\
\hline Sorghum bicolor $\mathrm{x} S$. bicolor var. sudanese & Sorghum-sudangrass & Ithaca Agway, N.Y. & 100 \\
\hline Fagopyrum esculentum & Buckwheat & Ithaca Agway, N.Y. & 173 \\
\hline Vigna unguiculata (inoculant: Bradyrhizobium B sp. vigna) & Cowpea & Peaceful Valley Farm Supply, Grass Valley, Calif. & 184.6 \\
\hline Crotolaria juncea (inoculant: Bradyrhizobium B sp. vigna) & Sunnhemp & Peaceful Valley Farm Supply, Grass Valley, Calif. & 123.1 \\
\hline Trifolium alexandrinum (inoculant: Rhizobium bv. trifolii) & Berseem clover & Peaceful Valley Farm Supply, Grass Valley, Calif. & 71.5 \\
\hline Tagetes erecta L.cv CrackerJack & Marigold & Stokes Seeds Inc., Fredonia, N.Y. & 12.3 \\
\hline Brassica juncea & Brown mustard & Minn-Dak Growers, Grand Forks, N.D. & 13.4 \\
\hline Rudbeckia hirta & Black-eyed susan & Peaceful Valley Farm Supply, Grass Valley, Calif. & 43.1 \\
\hline Sorgastrum avenaceum & Indiangrass & Prairie Nursery, Inc., Westfield, Wisc. & 73.1 \\
\hline Panicum virgatum & Switchgrass & Prairie Nursery, Inc., Westfield, Wisc. & 73.1 \\
\hline Triticum aestivum $\mathrm{x}$ Secale cereale & Triticale & Grower's Stock & 106 \\
\hline
\end{tabular}

but were tilled periodically to keep weeds in control. The field was irrigated two additional times during the growing season and was weeded by hand once per month. On 2 Oct. $2001,0.5 \mathrm{~m}^{2}$ of aboveground biomass was cut at the soil line, dried at $45^{\circ} \mathrm{C}$ for 1 week, and then weighed.

Cover crop residue was shallowly incorporated on 17 Apr. 2002. All cover crops, except the indiangrass, switchgrass, brown mustard, black-eyed susan, and berseem clover, were killed by frost the previous fall. On 6 May 2002, soils were harvested from each plot, brought to Ithaca, N.Y., and covered with a tarp to prevent wetting.

Soil from each field plot was thoroughly mixed using the method described by Dick et al. (1996). A 1-kg aliquot was removed using a sterilized hand trowel and placed in individual zip-lock bags, packed with a cooling agent and sent overnight to the Diagnostic Service at Michigan State University (East Lansing, Mich.) for analysis of the numbers and identity of plant pathogenic nematodes residing in the bulk soil.

On 9 May, each of the soils was mixed with perlite, $20 \% \mathrm{v} / \mathrm{v}$ in $3.8-\mathrm{L}$ pots, and planted with strawberry transplants, cv. Jewel (Krohne Nursery, Hartford, Mich.), to obtain 20 potted plants per soil treatment. Additional soil from the bare fallow plot was surrounded with a polyethylene tarp, covered, and fumigated with 99:1 methyl bromide: chloropicrin (Brom-O-Gas; Great Lakes Chemical Corp., West Lafayette, Ind.). After 1 week, the tarp was removed and soil from this treatment was thoroughly aerated and mixed with perlite before being planted to strawberries. Potted plants were randomly distributed on a concrete pad, and a complete fertilizer was supplied to each potted plant through a spaghetti tube drip irrigation system at the rate of $100 \mathrm{ppm} \mathrm{N}$ per irrigation event.

Stolon production was assessed twice during the first growing season, July 2002 and Sept. 2002. Runners from each pot were cut, counted, and placed into labeled paper bags. After oven drying $\left(45^{\circ} \mathrm{C}\right)$ for 1 week, runners were weighed and biomass discarded.

To help protect plants from winter damage, pots were placed in a trench in late autumn, covered with straw for winter, then the straw was removed in early spring. Plants began to flower in mid-May with the first harvest on 16 June 2003. Berries were separated at harvest into marketable and unmarketable berries. Marketable berries were those $8 \mathrm{~g}$ or larger and relatively free of blemish. Unmarketable berries were those either damaged by disease or pest or less than $8 \mathrm{~g}$. Berries were harvested until plants were completely finished producing fruit, with the last harvest occurring on 15 July. Yield was calculated as the sum of the marketable and unmarketable fruit from each individual potted plant. The number of stolons produced by each plant was counted before whole-plant harvest and dried.

Immediately after completing the fruit harvest, plants were qualitatively assessed as vigorous, weak (single shoot protruding from the stem with few leaves), or dead. At this time, the topmost portion of each plant was removed, leaving only an intact crown behind. The number of stolons produced in each pot was recorded. The foliage and stolons were dried at $45{ }^{\circ} \mathrm{C}$ for 2 weeks, and weighed.

Within 1 week of removing the foliar biomass, five plants were selected from each cover crop treatment. Root systems were rinsed of soil by placing the plant into clean water and gently massaging the soil into solution with the water. Root systems were viewed and ranked from one to five using the procedure of Wing et al. (1995) and then were dried at $45{ }^{\circ} \mathrm{C}$ for 1 week to determine root biomass.

Field experiment. In 1999, a study was initiated on a site at the Cornell Orchards, Ithaca, N.Y., in a field consisting of a Collamer silt loam, typic Hapludalf soil, pH 5.9, and $5.7 \%$ organic matter. The field had been planted to strawberry since 1992 and was shallowly plowed and disked before the start of the experiment. Four replicate blocks of eight treatments, consisting of five cover crop rotations and three different control treatments, were arranged in a randomized complete block design with $3 \times 5$-m plots.

Three control treatments consisted of 1) a mowed weedy fallow with annual fall tilling (white clover was the predominant weedy species), 2) weedy fallow followed by methyl bromide fumigation (99:1 methyl bromide: chloropicrin; Brom-O-Gas; Great Lakes Chemical Corp.) in Spring 2001 before planting, and 3) a continuation of strawberries for 2 more years. Cover crop treatments were sown in Aug. 1999 and consisted of 4) perennial alfalfa (Medicago sativa), 5) three consecutive rotations of brown mustard, and 6) three rotations of consecutive species: hairy vetch (Vicia villosa) followed by marigold ('Nema-gone') and then rye; 7) kale (Brassica oleracea var Winterbor) followed by sweet corn (Zea mays var Saccharata) and then rye; and 8) oats ('Newdak') followed by sudgangrass and rye. Rotational crops were incorporated by tillage in Spring 2000 and again in late Summer 2000. Each subsequent rotation was sown after tilling. The rotation with sweet corn and the continuous strawberry treatment received additional nitrogen fertilizer, but the other treatments did not.

Rooted runners of the cultivar 'Jewel' were planted on 17 May 2001 at a spacing of $50 \mathrm{~cm}$ in row and $1.25 \mathrm{~m}$ between rows. Transplants were planted in rows perpendicular to previous strawberry rows. Standard cultural practices were used (Pritts and Handley, 1997). Weeds were controlled by mechanical cultivation and by hand weeding during the period of flowering and harvest with applications of chemical herbicides made after field renovation. Late frosts in the Spring of 2002 require the use of the overhead irrigation system to prevent frost damage. The number of frost-killed blossoms, identified by blackened receptacles, was counted for 1-m row length per plot.

During the 2001 growing season, soil compaction and initial weediness were measured. Soil compaction was measured using a Dickie-John cone penetrometer on 11 June 2001. Measurements were made in five locations between plants in each plot at depths from $7.5 \mathrm{~cm}$ to $52.5 \mathrm{~cm}$ at $\approx 7.5-\mathrm{cm}$ increments. To assess the effect of the preplant treatments on weed emergence, a representative $0.5-\mathrm{m}^{2}$ area was selected for each plot. On 10 July 2001, the initial flush of weeds was cut at soil level and separated by type. Weeds from each replicate were then identified as close to species as possible and then were oven-dried for 1 week at $45{ }^{\circ} \mathrm{C}$ after which samples were weighed. Weeds were grouped into grasses or broadleaves for statistical analysis. 
To assess the vegetative productivity of each treatment, stolon production and foliar biomass were measured. Near the end of the 2001 growing season, the number of stolons produced in a representative area of $0.5 \mathrm{~m}^{2}$ was counted in each plot. Foliar biomass was harvested on 17 July 2002 from a representative area of $0.5 \mathrm{~m}^{2}$ in each plot. Because of increasing variation within plots, foliage produced in 2003 was harvested from a representative square meter in each plot on 28 July. The date of flowering in each plot was noted, and the number of frost-injured flowers was counted. Immediately after harvesting the foliar biomass in both 2002 and 2003, the foliage was placed in a drying oven $\left(45^{\circ} \mathrm{C}\right)$ for 1 week and then weighed.

The fruit harvest in 2002 was from 19 June to 11 July, and in 2003 from 19 June through 17 July. In 2002, the field was picked every $3 \mathrm{~d}$; in 2003 , the field was picked several times per week depending on the volume of ripe berries. Harvest ended once the average berry size dropped below marketable size. Berries were harvested from a representative $2 \mathrm{~m}$ of row in each plot. At the time of picking, berries were separated according to marketability. Marketable berries were those larger than $8 \mathrm{~g}$ and with no obvious blemish. Unmarketable berries were those with obvious insect damage, apparent rot, small size, or some kind of physiological disorder such as sunscald or water cracking. Immediately after harvest, berries were placed in a $0{ }^{\circ} \mathrm{C}$ cooler for up to $24 \mathrm{~h}$ until they were weighed and counted.

Strawberry roots and rhizosphere soil from each treatment were assessed for nematodes, fungi, and bacteria during the summer of 2002. Nematodes were determined by selecting one representative plant and at least $1 \mathrm{~kg}$ of adhering soil, which was removed from each plot on 22 May 2002. Plants and soil were individually bagged, cooled, packaged in an insulated cooler, and sent for analysis to the Diagnostic Service at Michigan State University (East Lansing, Mich.). Nematodes were extracted from the root and rhizosphere soil, and were identified and counted.

Pieces of strawberry roots to be analyzed for fungal infection were harvested during June 2002 using the sampling technique described by Yuen et al. (1991). Five positions were selected for each plot at locations within $2 \mathrm{~cm}$ of strawberry crowns. Roots were removed from bulk soil by using forceps, then placed in a zip-lock bag, and stored in a cooler $\left(5^{\circ} \mathrm{C}\right)$ for up to $14 \mathrm{~d}$ until sterilizing and plating (Mazzola, 1998). At the time of separating bulk soil and roots, small composite aliquots consisting of $\approx 10 \mathrm{~g}$ from each plot were thoroughly mixed by shaking (Dick et al., 1996) and placed in a cooler $\left(5^{\circ} \mathrm{C}\right)$ for 2 weeks until used in soil microbial analyses. A composite soil sample was weighed, then allowed to airdry at $22{ }^{\circ} \mathrm{C}$, at which time it was weighed again. Percent moisture was calculated for each plot using the following formula: ((moist weight - dry weight)/dry weight $) \cdot 100=\%$ moisture (Josephson et al., 2000).
Within 1 week after sampling, root segments were rinsed of soil on 1-mm mesh screens using tap water to remove surface soil, sterilized in $10 \%$ commercial bleach (Clorox, 6.75\% sodium hypochlorite), and then triple rinsed with distilled water. Root segments were selected and prepared for plating according to the process of Pinkerton et al. (2002). The three agar types used were PDA-amended with Rose Bengal and streptomycin for culturing all fungi (PDA+; Dhingra and Sinclair, 1995), PARP for culturing Pythium spp. (Jeffers and Martin, 1986), and Ko and Hora (1971) for culturing Rhizoctonia spp.

After 10 to 15 roots were plated on each agar type, plates were then incubated and viewed as prescribed for each agar type (Dhingra and Sinclair, 1995; Jeffers and Martin, 1986; Ko and Hora, 1971) with the exception that incubation temperature was $20^{\circ} \mathrm{C}$ and that all plates were initially incubated in the dark for the first day. Root segments were identified has having positive fungal infections if fungi protruded from the root segments and grew into the agar medium. The proportion of positive infections out of the number of roots segments plated on each of the three agar types was recorded.

Within 2 weeks of sampling, the roots and rhizosphere soil were prepared for microbial analysis. Each sample was prepared in dilution series of $1.0 \times \mathrm{E}^{-1}$ to $1.0 \times \mathrm{E}^{-6}$ using the method described by Josephson et al. (2000) adapted to use $0.1 \mathrm{M}$ phosphate buffer pH $7.0\left(\mathrm{NaH}_{2} \mathrm{PO}_{3} \cdot \mathrm{H}_{2} \mathrm{O}\right.$ and $\left.\mathrm{Na}_{2} \mathrm{HPO}_{4}\right)$ as the substrate. The serial dilutions were plated on both PDA+ and R2A agars for fungi and bacteria, respectively. Plates were incubated in the dark at $20^{\circ} \mathrm{C}$ for 72 to $96 \mathrm{~h}$ for the PDA+ plates and 96 to $144 \mathrm{~h}$ for the R2A plates. The length of $144 \mathrm{~h}$ allowed for excessive growth, eliminating one replicate from the continuous strawberry treatment from statistical analysis. Plate counts of colony-forming units (CFUs) of both bacteria and fungi were made using a dissecting scope. CFU counts were calculated to take soil weight and moisture into account using the following equation: ((1/dilution factor) $\bullet$ $\mathrm{CFU} \cdot(1 /$ dry weight $))=\mathrm{CFU} \cdot \mathrm{g}$ dry soil ${ }^{-1}$. A $\log 10$ transformation of CFU $\cdot \mathrm{g}$ dry soil ${ }^{-1}$ was performed on the data before analysis (Josephson et al., 2000).

During the week of 28 Oct. 2002, five plants and adhering soil per replicate were harvested to a depth of $20 \mathrm{~cm}$ and analyzed for the presence of pathogenic fungi and bacteria. Because of higher infection by Fusarium spp. and Cylindrocarpon spp. and lower infection by Rhizoctonia spp. in diagnostic samples (data not shown), agar selective for Fusarium and Cylindrocarpon was used. Plates were incubated as described for each type (Jeffers and Martin, 1986; Nash and Snyder, 1962). PDA+ plates were incubated in conditions similar to PARP.

All data were analyzed using SAS (Cary, N.C.). The GLM procedure was used to determine the $F$-statistic and to determine treatment means and variance. Means separation was performed by LSD to compare cover crop treatments with the various control treatments. Comparisons among the various cover crop treatments were less meaningful so a multiple range test was not used. Correlations were performed using the correlation procedure within the GLM procedure. Orthogonal contrasts were performed when appropriate.

\section{Results}

Pot study. Indicators of replant disorder were reduced by many of the cover crop treatments when compared with the bare fallow treatment (Table 2). In general, strawberry plants performed less well after buckwheat, sudangrass, and triticale incorporation, and visual symptoms of replant disorder were particularly evident in the bare fallow, cowpea, buckwheat, black-eyed susan, and triticale treatments. Freezing temperatures in the Winter of 2003 caused the death of many crowns and severely weakened some plants. Plants from the bare fallow treatment were significantly more damaged over the winter compared with other treatments $(P<$ $0.035)$ and were significantly less likely to produce fruiting buds than healthy plants $(P<$ 0.0001).

Methyl bromide fumigation did not result in superior performance of strawberry plants; rather, yield and root biomass were significantly lower than most other treatments (Table 2). Although plants from the bare fallow treatment also had low yield, root biomass was not as low as plants from the fumigation treatment. Compared with both of the control treatments (bare fallow and fumigation), fruit production was greater on average after cover crops $(P<0.0002)$.

Fruit production was greatest after indiangrass, switchgrass, brown mustard, and millet. With switchgrass and Japanese millet treatments, yields were high, whereas several vegetative variables (foliar biomass, stolon production, and root vigor) were low. With indiangrass and brown mustard treatments, both vegetative and fruit production variables were high. Overall, there was no association between vegetative vigor and fruit production, suggesting that cover crops may have specific effects on components of strawberry plant growth.

The soil from the field site had low levels of $P$. penetrans and other plant parasitic nematodes before planting strawberries (Table 2). Sunnhemp and millet had $P$. penetrans counts of 86 and 78 per $100 \mathrm{~cm}^{3}$ soil, respectively, but these higher infestation levels were still lower than the range commonly associated with symptoms of disease (LaMondia and Martin, 1989; Wing et al., 1994).

Neither the accumulated biomass of the preplant cover crops nor the production of stolons in 2002 was significantly correlated with fruit yield. However, root vigor was positively correlated with fruit yield $(\mathrm{r}=$ $0.45, P<0.0001)$, foliar biomass $(\mathrm{r}=0.474$, 
Table 2. Cover crop biomass at the end of 2001, lesion nematode levels in spring 2002, and the vegetative and fruiting response of strawberries in 2002 and 2003 grown in pots with soils from the cover crop plots.

\begin{tabular}{|c|c|c|c|c|c|c|c|c|c|c|}
\hline Treatment & $\begin{array}{l}\text { Cover Crop } \\
\text { Dry Biomass }^{\mathrm{z}}\end{array}$ & $\begin{array}{l}\text { Root Lesion } \\
\text { Nematodes }^{y}\end{array}$ & $\begin{array}{l}\text { Stolon No. } \\
\text { in } 2002\end{array}$ & $\begin{array}{l}\text { Stolon Dry } \\
\text { Biomass in } \\
2002(\mathrm{~g})\end{array}$ & $\begin{array}{c}\text { Fruit No. per } \\
\text { Plant in } \\
2003\end{array}$ & $\begin{array}{c}\text { Fruit Fresh } \\
\text { Biomass in } \\
2003 \text { (g/plant) }\end{array}$ & $\begin{array}{c}\text { Foliar Dry } \\
\text { Biomass in } \\
2003(\mathrm{~g})\end{array}$ & $\begin{array}{l}\text { Stolon No. per } \\
\text { Plant in } \\
2003\end{array}$ & Root Vigor $^{x}$ & $\begin{array}{l}\text { Root Dry } \\
\text { Biomass } \\
\text { (g) }\end{array}$ \\
\hline Indiangrass & 12.6 & 12 & $7.75 \mathrm{a}^{\mathrm{w}}$ & $13.17 \mathrm{a}$ & $43.90 \mathrm{a}$ & $275.0 \mathrm{a}$ & $24.05 \mathrm{a}$ & $0.900 \mathrm{ab}$ & $3.6 \mathrm{ab}$ & $35.60 \mathrm{abcd}$ \\
\hline Switchgrass & 79.2 & 2 & $5.25 \mathrm{ef}$ & $8.17 \mathrm{de}$ & $37.71 b c$ & $247.9 \mathrm{ab}$ & $19.01 \mathrm{bcd}$ & $0.059 \mathrm{e}$ & $3.0 \mathrm{bcd}$ & $41.74 \mathrm{a}$ \\
\hline Millet & 195.8 & 78 & $6.30 \mathrm{bcd}$ & $8.76 \mathrm{cde}$ & $40.06 \mathrm{ab}$ & $237.6 \mathrm{abc}$ & $19.36 \mathrm{bcd}$ & 0.579 abcde & $3.3 \mathrm{abc}$ & $33.78 \mathrm{abcd}$ \\
\hline Marigold & 219.4 & 0 & $7.15 \mathrm{ab}$ & $10.83 \mathrm{bc}$ & $39.30 \mathrm{abc}$ & $227.9 \mathrm{bcd}$ & $18.27 \mathrm{~cd}$ & 0.300 cde & $3.4 \mathrm{abc}$ & $41.56 \mathrm{ab}$ \\
\hline Clover & 274.7 & 2 & $7.80 \mathrm{a}$ & $12.83 \mathrm{ab}$ & $35.56 \mathrm{bcd}$ & $209.3 \mathrm{cde}$ & $22.34 \mathrm{abc}$ & $0.737 \mathrm{abcd}$ & $3.5 \mathrm{ab}$ & $44.44 \mathrm{a}$ \\
\hline Buckwheat & 31.1 & 2 & 5.30 ef & $9.21 \mathrm{cde}$ & $29.95 \mathrm{de}$ & $184.9 \mathrm{e}$ & $17.20 \mathrm{~d}$ & $0.895 \mathrm{ab}$ & $2.7 \mathrm{de}$ & $35.84 \mathrm{abcd}$ \\
\hline Triticale & 194.2 & 2 & $5.70 \mathrm{cde}$ & $7.95 \mathrm{e}$ & $31.26 \mathrm{de}$ & $182.4 \mathrm{e}$ & $17.85 \mathrm{~cd}$ & $0.684 \mathrm{abcd}$ & $2.4 \mathrm{e}$ & $24.08 \mathrm{~d}$ \\
\hline Sunnhemp & 196.8 & 86 & $5.00 \mathrm{ef}$ & $8.58 \mathrm{de}$ & 26.06 ef & $172.7 \mathrm{e}$ & $22.88 \mathrm{a}$ & $1.056 \mathrm{a}$ & $3.9 \mathrm{a}$ & $38.64 \mathrm{abc}$ \\
\hline Fumigation & 0 & 0 & $7.05 \mathrm{ab}$ & $7.79 \mathrm{e}$ & $24.06 \mathrm{f}$ & $159.4 \mathrm{f}$ & $19.06 \mathrm{bcd}$ & $0.778 \mathrm{abc}$ & $3.8 \mathrm{ab}$ & $28.38 \mathrm{~cd}$ \\
\hline Bare fallow & 0 & 14 & $4.55 \mathrm{f}$ & $7.51 \mathrm{ef}$ & $30.84 \mathrm{de}$ & $189.2 \mathrm{e}$ & $18.53 \mathrm{~cd}$ & $0.211 \mathrm{de}$ & $3.1 \mathrm{bc}$ & $39.34 \mathrm{abc}$ \\
\hline S.E. & & & 0.41 & 0.92 & 2.5 & 16.2 & 4.5 & 0.24 & 0.29 & 5.5 \\
\hline
\end{tabular}

${ }^{\mathrm{z}}$ Dried weight $(\mathrm{g})$ from $0.5 \mathrm{~m}^{2}$ of established cover crop in late Fall.

${ }^{\mathrm{y}}$ Number of nematodes in $100 \mathrm{~cm}^{3}$ soil.

${ }^{x}$ Rank scale 1 to 5 (dead to healthy).

"Numbers in a column followed by the same letter are not statistically different at $P<0.05$ using the least significant difference test.

$P<0.0001)$, root biomass $(\mathrm{r}=0.50, P<$ $0.0001)$, and 2003 stolon production $(\mathrm{r}=$ $0.36, P<0.0027)$

Field experiment. Replant disorder was observed in the continuous strawberry plots before the end of the first growing season as stolon production (2001) in the continuous strawberry treatment was low. Plants continued to grow poorly in the subsequent two growing seasons. Foliar biomass in continuous strawberry plots was significantly lower than all other treatments in both seasons $(P<$ 0.0001 ) (Table 3 ), and a similar trend existed for fruit yield in both 2002 and 2003 (Table 4). The number of frost-killed blossoms in 2002 also was highest in the continuous strawberry treatments that flowered 3 d earlier than other plots. The incidence of frost injury was negatively associated $(\mathrm{r}=-0.42, P<$ 0.02 ) with the average individual (marketable) berry size in 2002 . Individual berry size was larger in 2003 than in 2002, with fumigation, brown mustard, and kale/sweet corn/ rye (KCR) rotations exhibiting large fruit size in both years. Plants from continuous strawberry plots had lower yield than fumigated or cover cropped plots in both $2002(P<0.0015$ and $<0.0001$, respectively) and 2003 (both $P<0.0001)$.

Table 3. Vegetative characteristics of strawberry plants established in 2001 and grown in the field after various 2 -y cover crop rotations or fumigation with methyl bromide.

\begin{tabular}{|c|c|c|c|c|}
\hline Treatment & $\begin{array}{l}\text { Stolon No. per } \\
\text { Plot in } \\
2001\end{array}$ & $\begin{array}{c}\text { Dry Biomass } \\
\text { per } 1 \mathrm{~m} \text { of } \\
\text { Row in } 2002(\mathrm{~g})\end{array}$ & $\begin{array}{c}\text { Dry Biomass } \\
\text { per } 1 \mathrm{~m} \text { of } \\
\text { Row in } 2003(\mathrm{~g})\end{array}$ & Root Vigor \\
\hline Fumigation & $50.5 \mathrm{ab}^{\mathrm{y}}$ & $438.3 \mathrm{a}$ & $458.7 \mathrm{a}$ & $2.980 \mathrm{~b}$ \\
\hline Kale/sweet corn/rye & $50.0 \mathrm{ab}$ & $369.8 \mathrm{bc}$ & $351.5 \mathrm{~b}$ & $2.825 \mathrm{c}$ \\
\hline Mowed fallow & $50.5 \mathrm{ab}$ & $267.1 \mathrm{de}$ & $322.1 \mathrm{bc}$ & $3.175 \mathrm{a}$ \\
\hline Oat/sudangrass/rye & $47.7 \mathrm{ab}$ & $325.7 \mathrm{~cd}$ & $327.1 \mathrm{~b}$ & $2.840 \mathrm{c}$ \\
\hline Hairy vetch/marigold/rye & $46.7 \mathrm{ab}$ & $395.9 \mathrm{ab}$ & $345.6 \mathrm{~b}$ & $3.015 \mathrm{~b}$ \\
\hline Alfalfa & $43.2 \mathrm{~b}$ & 316.8 cde & $330.5 \mathrm{~b}$ & $3.053 \mathrm{ab}$ \\
\hline Mustard & $54.0 \mathrm{a}$ & $299.4 \mathrm{de}$ & $262.5 \mathrm{c}$ & $3.125 \mathrm{a}$ \\
\hline Strawberry & $44.7 \mathrm{~b}$ & $197.8 \mathrm{f}$ & $222.6 \mathrm{~d}$ & $2.551 \mathrm{~d}$ \\
\hline $\mathrm{SE}$ & 3.7 & 24.2 & 84.5 & 0.090 \\
\hline
\end{tabular}

${ }^{2}$ Rank scale $1-5$ (dead - healthy).

${ }^{y}$ Numbers in a column followed by the same letter are not statistically different at $P<0.05$ using the using the LSD test.

Rotations had significant effects on soil physical properties and weediness (Table 5). Continuous strawberry plots were the least compacted, whereas the multiple species rotations and alfalfa were most compacted. Not surprisingly, mowed fallow plots were the weediest, whereas fumigated plots were the least weedy. Neither of these two variables, however, was associated with strawberry root health or plant performance.

Fungal CFUs and overall fungal infection in the fall was negatively correlated $(P<$ $0.05)$ with foliar biomass in $2002(\mathrm{r}=-0.4$, $\mathrm{r}=-0.56)$ and $2003(\mathrm{r}=-0.35, \mathrm{r}=-0.52)$, respectively. Infection by Rhizoctonia spp. was highest in continuous strawberry plots, $\mathrm{KCR}$, and rotations containing legumes ( $\mathrm{Ta}$ ble 6) and was negatively correlated with root vigor $(\mathrm{r}=-0.59, P<0.05)$ and marketable yield in $2003(\mathrm{r}=-0.37, P<0.04)$. Other potential pathogens were not consistently correlated with the occurrence of replant symptoms. Nematode levels were generally low (Table 5) and not considered to have played a role in replant symptoms in this site. Similarly, the level of Fusarium-type infection was low (1.7\%). Infection by Pythium spp. across treatments was relatively low in both summer and fall $(19.7 \%$ and $5 \%$, re- spectively). The level of Pythium infection at the summer sampling time was negatively correlated with bacterial CFUs $(\mathrm{r}=-0.45, P<$ 0.03). Although bacterial CFUs were highest in the fumigation treatment, their levels were relatively similar across treatments (Table 6).

Across all treatments, there was a significant correlation between total weeds and both the level of infection by Pythium ( $\mathrm{r}=0.41$, $P<0.02)$ and fungal CFUs $(\mathrm{r}=0.37, P<$ 0.04). The level of fungal CFUs in the multiple species rotations was generally lower than those of the single species rotations $(P<0.027)$.

\section{Discussion}

Without soil amelioration, replanted strawberries in both studies exhibited characteristic replant disorder. Continuously replanted strawberries exhibited poor growth, root health, and productivity and an increase in frost injury in the field study. This latter effect was likely the result of earlier flowering in weaker plants incited by greater heat absorption and radiation in soil with less foliar cover. The only measured variable that was favorable in continuous strawberries was the low level of soil compaction.

Methyl bromide fumigation typically results in high yield and improved plant productivity in replant sites (Hancock et al., 2001; Larson and Shaw, 2000; Rieger et al., 2001). In both studies, fumigation with methyl bromide resulted in good vegetative growth; however, fruit yield was not exceptional the year after planting. It is possible that the balance between vegetative and reproductive growth was more optimal in other treatments than in fumigated plots the first fruiting year. Increased foliar biomass after fumigation may have resulted from additional nutrients made available through decaying organic material and the inhibition of nitrifying bacteria (Hansen et al., 1990; Miller et al., 1997; Wilhelm 1965). In the second year of the field study, yields were 
Table 4. Vegetative characteristics of established strawberry plants in the field after various cover crop rotations.

\begin{tabular}{|c|c|c|c|c|c|c|c|}
\hline Treatment & $\begin{array}{l}\text { Frost-Killed Buds } \\
\text { in } 2002^{z}\end{array}$ & $\begin{array}{l}\text { Total Fresh } \\
\text { Yield in } \\
2002\left(\mathrm{~g} \cdot \mathrm{m}^{-1}\right)\end{array}$ & $\begin{array}{l}\text { Marketable Fresh } \\
\text { Yield in } \\
2002(\mathrm{~g})\end{array}$ & $\begin{array}{l}\text { Individual Fresh } \\
\text { Fruit Wt in } \\
2002(\mathrm{~g})\end{array}$ & $\begin{array}{l}\text { Total Fresh } \\
\text { Yield in } \\
2003\left(\mathrm{~g} \cdot \mathrm{m}^{-1}\right)\end{array}$ & $\begin{array}{c}\text { Marketable Fresh } \\
\text { Yield in } \\
2003\left(\mathrm{~g} \cdot \mathrm{m}^{-1}\right)\end{array}$ & $\begin{array}{l}\text { Individual Fresh } \\
\text { Fruit Wt in } \\
2003(\mathrm{~g})\end{array}$ \\
\hline Fumigation & $3.25 \mathrm{ab}^{\mathrm{y}}$ & $7941.7 \mathrm{ab}$ & $4782.5 \mathrm{bc}$ & $10.99 \mathrm{abc}$ & $11038.4 \mathrm{a}$ & $6090.8 \mathrm{a}$ & $14.65 \mathrm{a}$ \\
\hline Kale/sweet corn/rye & $5.00 \mathrm{ab}$ & $8405.8 \mathrm{ab}$ & $5495.1 \mathrm{ab}$ & $11.07 \mathrm{ab}$ & $9903.0 \mathrm{ab}$ & $5338.0 \mathrm{ab}$ & $13.25 \mathrm{~cd}$ \\
\hline Mowed fallow & $1.75 \mathrm{~b}$ & $8087.9 \mathrm{ab}$ & $5041.5 \mathrm{bc}$ & $10.34 \mathrm{~b}-\mathrm{f}$ & $8481.2 \mathrm{~b}$ & $4748.9 \mathrm{~b}$ & $13.37 \mathrm{bcd}$ \\
\hline Oat/sudangrass/rye & $2.50 \mathrm{ab}$ & $8696.9 \mathrm{ab}$ & $5439.5 \mathrm{ab}$ & $10.39 \mathrm{bcd}$ & $8438.3 \mathrm{~b}$ & $4839.3 \mathrm{~b}$ & $14.51 \mathrm{ab}$ \\
\hline Vetch/marigold/rye & $2.75 \mathrm{ab}$ & $8252.3 \mathrm{ab}$ & $5211.3 \mathrm{bc}$ & $10.76 \mathrm{~b}-\mathrm{e}$ & $8361.2 \mathrm{~b}$ & $4619.1 \mathrm{~b}$ & $13.39 \mathrm{bcd}$ \\
\hline Alfalfa & $3.25 \mathrm{ab}$ & $7427.6 \mathrm{~b}$ & $4309.8 \mathrm{c}$ & $9.57 \mathrm{~b}-\mathrm{f}$ & $8051.5 \mathrm{~b}$ & $4387.1 \mathrm{~b}$ & $12.65 \mathrm{~d}$ \\
\hline Mustard & $2.25 \mathrm{ab}$ & $9100.4 \mathrm{a}$ & $6404.1 \mathrm{a}$ & $12.92 \mathrm{a}$ & $7691.6 \mathrm{~b}$ & $4503.2 \mathrm{~b}$ & $14.25 \mathrm{abc}$ \\
\hline Strawberry & $6.00 \mathrm{a}$ & $5048.2 \mathrm{c}$ & $2706.2 \mathrm{~d}$ & $8.33 \mathrm{f}$ & $4612.7 \mathrm{c}$ & $2410.8 \mathrm{c}$ & $12.70 \mathrm{~d}$ \\
\hline SE & 1.70 & 561 & 444.3 & 0.89 & 952.5 & 575.4 & 0.5 \\
\hline
\end{tabular}

${ }^{\mathrm{z} N u m b e r}$ of frost-killed buds per $\mathrm{m}$ of row.

${ }^{\mathrm{y}}$ Numbers in a column followed by the same letter are not statistically different at $P<0.05$ using the LSD test.

Table 5. Effects of cover crop rotations on soil compaction, weeds, and root lesion (Pratylenchus penetrans), pin (Paratylenchus sp., and lance (Hoplolaimus sp.) nematodes.

\begin{tabular}{|c|c|c|c|c|c|c|c|c|c|}
\hline Treatment & $\begin{array}{c}\text { Compaction } \\
\text { at } 15 \mathrm{~cm}^{\mathrm{z}}\end{array}$ & $\begin{array}{l}\text { Compaction } \\
\text { at } 22.5 \mathrm{~cm}^{\mathrm{z}}\end{array}$ & Total Weeds ${ }^{y}$ & Grass Weeds ${ }^{y}$ & Broadleaf Weeds ${ }^{y}$ & Total Nematodes ${ }^{x}$ & Root Lesion $^{\mathrm{x}}$ & $\operatorname{Pin}^{x}$ & Lance $^{\mathrm{x}}$ \\
\hline Fumigation & $1.06 \mathrm{~cd}^{\mathrm{w}}$ & $1.71 \mathrm{a}$ & $5.9 \mathrm{c}$ & $4.15 \mathrm{~b}$ & $1.57 \mathrm{c}$ & 0 & 0 & 0 & 0 \\
\hline Kale/sweet corn/rye & $1.48 \mathrm{ab}$ & $1.92 \mathrm{a}$ & $9.3 \mathrm{c}$ & $1.00 \mathrm{~b}$ & $6.85 \mathrm{bc}$ & 3.0 & 0.5 & 0 & 2.5 \\
\hline Mowed fallow & $1.35 \mathrm{bc}$ & $1.79 \mathrm{a}$ & $35.5 \mathrm{a}$ & $27.58 \mathrm{a}$ & $7.36 \mathrm{bc}$ & 4.0 & 2.5 & 1.0 & 0.5 \\
\hline Oat/sudangrass/rye & $1.74 \mathrm{a}$ & $1.93 \mathrm{a}$ & $26.2 \mathrm{ab}$ & $4.15 \mathrm{~b}$ & $21.94 \mathrm{a}$ & 0.5 & 0.5 & 0 & 0 \\
\hline Vetch/marigold/rye & $1.47 \mathrm{ab}$ & $1.89 \mathrm{a}$ & $18.4 \mathrm{bc}$ & $2.33 \mathrm{~b}$ & $14.92 \mathrm{ab}$ & 1.5 & 0.5 & 0.5 & 0.5 \\
\hline Alfalfa & $1.64 \mathrm{ab}$ & $1.41 \mathrm{~b}$ & $16.6 \mathrm{bc}$ & $7.10 \mathrm{~b}$ & $9.53 \mathrm{ab}$ & 1.5 & 1.0 & 0 & 0.5 \\
\hline Mustard & $1.41 \mathrm{~b}$ & $1.77 \mathrm{a}$ & $11.5 \mathrm{bc}$ & $2.18 \mathrm{~b}$ & $6.80 \mathrm{bc}$ & 2.0 & 1.5 & 0 & 0.5 \\
\hline Strawberry & $0.88 \mathrm{c}$ & $0.83 \mathrm{c}$ & $18.6 \mathrm{bc}$ & $1.05 \mathrm{~b}$ & $16.49 \mathrm{ab}$ & 0 & 0 & 0 & 0 \\
\hline SE & 0.02 & 0.02 & 6.3 & 3.8 & 4.8 & 1.4 & 0.9 & 0.4 & 0.9 \\
\hline
\end{tabular}

${ }^{\mathrm{z}}$ Compaction determined by a soil probe $(\mathrm{MPa})$.

${ }^{\mathrm{y}} \mathrm{g}$ dry weight $/ \mathrm{m}^{2}$.

${ }^{\mathrm{x}}$ Values are expressed as number/g root tissue.

w Numbers in a column followed by the same letter are not statistically different at $P<0.05$ using the LSD test.

highest in fumigated plots, nematodes were not found, and fungal CFUs were low.

Several cover crops also suppressed pathogens and improved yield relative to continuous strawberries. Growing prairie grasses (indiangrass and switchgrass) before planting strawberries was associated with good productivity and root biomass. Summers (1999) found that rotations of prairie species led to greater soil aggregate stability and a general improvement of soil quality compared with annual grass rotations. This might, in part, explain the poorer performance from the annual grasses, sudangrass, and triticale. The high carbon-to-nitrogen ratio in these annual species had the potential for creating nutrient imbalances in the subsequent strawberry planting. Berseem clover, a nitrogen-fixing species, appeared to promote vegetative growth in the subsequent strawberry planting, but yield was not pro- portional to plant biomass, similar to the effect of fumigation.

Sunnhemp was associated with higher levels of nematodes and low productivity, although we cannot state that nematodes were the cause of poor productivity because root vigor and biomass were high with this treatment.

Reynolds et al. (2000) and Jagdale et al. (2000) observed that populations of $P$. penetrans were reduced through rotations of marigold, leading to increases in tobacco yield and quality. Similarly, we found that the rotation of marigold with strawberry resulted in no detectable nematodes, high root vigor, and moderate fruit production.

Mazzola et al. (2002) found that rapeseed (Brassica napus) meal suppressed nematodes and Rhizoctonia in replanted soils. In our study, yield and root vigor were high, and levels of Pythium and Rhizoctonia were low, after a sequence of three sowings of brown mustard. A reduction in microbial pathogens incited by the biofumigation effect of the glucosinolate products released from the tissues of mustard species has led to increased plant vigor in other crop species (Black et al., 2003; Mazzola et al., 2001). Despite this initial response, the ameliorating effect of $B$. juncea on replant disorder may not be longlasting as yields were relatively lower the second fruiting year (Black et al., 2003; Ramirez-Villapudua and Muneckee, 1988).

Across both years, the multiple species rotations performed well, particularly the $\mathrm{KCR}$ treatment. These rotations also exhibited relatively low fungal CFUs and low levels of weeds. Strawberry plants after alfalfa did not perform well by any measure, and fungal CFUs were high. Strawberry plants after rotations of hairy vetch/marigold/rye and oat/sudangrass/rye performed

Table 6. Seasonal response of various soil microflora on strawberry roots after one year in the field after 2-y cover crop rotations.

\begin{tabular}{|c|c|c|c|c|c|c|c|c|}
\hline Treatment & $\begin{array}{l}\text { General Fungiz } \\
\text { (Summer) }\end{array}$ & $\begin{array}{l}\text { Pythium }{ }^{z} \\
\text { (Summer) }\end{array}$ & $\begin{array}{l}\text { Rhizoctonia }{ }^{z} \\
\text { (Summer) }\end{array}$ & $\begin{array}{l}\text { General Fungiz } \\
\text { (Fall) }\end{array}$ & $\begin{array}{l}\text { Pythium } \\
\text { (Fall) }\end{array}$ & $\begin{array}{l}\text { Fusarium } \\
\text { Type }^{z} \text { Fall }\end{array}$ & Bacterial CFU ${ }^{y}$ & Fungal CFU \\
\hline Fumigation & $31 \mathrm{ab}^{\mathrm{x}}$ & $20 \mathrm{~b}$ & $4 \mathrm{~b}$ & $30 \mathrm{ab}$ & $14 \mathrm{ab}$ & $6.7 \mathrm{bc}$ & $5.66 \mathrm{a}$ & $2.53 \mathrm{~d}$ \\
\hline Kale/sweet corn/rye & $29 \mathrm{ab}$ & $19 \mathrm{~b}$ & $17 \mathrm{a}$ & $23 \mathrm{ab}$ & $17 \mathrm{ab}$ & $8.3 \mathrm{ab}$ & $5.49 \mathrm{ab}$ & $2.95 \mathrm{bcd}$ \\
\hline Mowed fallow & $40 \mathrm{a}$ & $30 \mathrm{a}$ & $7 \mathrm{~b}$ & $20 \mathrm{ab}$ & $3 \mathrm{~b}$ & $8.3 \mathrm{ab}$ & $5.48 \mathrm{ab}$ & $3.07 \mathrm{~b}$ \\
\hline Oat/sudangrass/rye & $31 \mathrm{ab}$ & $30 \mathrm{a}$ & $2 \mathrm{~b}$ & $13 \mathrm{~b}$ & $0 \mathrm{~b}$ & $3.3 \mathrm{c}$ & $5.39 \mathrm{~b}$ & $2.99 \mathrm{abc}$ \\
\hline Vetch/marigold/rye & $26 \mathrm{~b}$ & $23 \mathrm{~b}$ & $20 \mathrm{a}$ & $33 \mathrm{a}$ & $28 \mathrm{a}$ & $3.3 \mathrm{c}$ & $5.52 \mathrm{ab}$ & $2.60 \mathrm{~cd}$ \\
\hline Alfalfa & $32 \mathrm{ab}$ & $22 \mathrm{~b}$ & $16 \mathrm{a}$ & $22 \mathrm{ab}$ & $0 \mathrm{~b}$ & $11.7 \mathrm{a}$ & $5.55 \mathrm{ab}$ & $3.41 \mathrm{a}$ \\
\hline Mustard & $41 \mathrm{a}$ & $18 \mathrm{~b}$ & $7 \mathrm{~b}$ & $13 \mathrm{~b}$ & $2 \mathrm{~b}$ & $6.7 \mathrm{bc}$ & $5.52 \mathrm{ab}$ & $3.08 \mathrm{ab}$ \\
\hline Strawberry & $25 \mathrm{~b}$ & $20 \mathrm{~b}$ & $20 \mathrm{a}$ & $19 \mathrm{ab}$ & $5 \mathrm{~b}$ & $1.7 \mathrm{c}$ & $5.40 \mathrm{ab}$ & $2.92 \mathrm{bcd}$ \\
\hline SE & 5 & 5 & 4 & 7 & 8 & 4.2 & 0.10 & 0.19 \\
\hline
\end{tabular}

${ }^{2}$ Percent of infected roots plated on general and fungal specific agar media (10-15 roots per media type).

y Values are transformed by $\log 10$.

${ }^{x}$ Numbers in a column followed by the same letter are not statistically different at $P<0.05$ using the LSD test. 
better than plants after continuous strawberries, but not statistically different from the mowed fallow control. The number of grassy weeds, however, was much higher in the mowed fallow treatment compared with multiple species rotations.

Fungal infection rates, particularly $R h i$ zoctonia, were negatively associated with vegetative biomass of the strawberry plants. Pythium populations were positively associated with weed biomass and negatively associated with bacterial CFUs, but neither Pythium nor bacteria appeared to be directly involved with replant disease in this study. Fusarium and nematodes also did not appear to play a role in replant disease in our study. LaMondia et al. (2002) did not find strong associations between cover crop rotation and isolation of Rhizoctonia or Pythium in two sites in Conn.

We demonstrated that, without amelioration, replanting strawberries can lead to a significant decline in plant vigor, growth, and yield. Rhizoctonia appeared to be associated with poor root health and productivity, but overall levels of fungal and bacterial populations were not good predictors of replant disorder. Fumigation led to improved vegetative growth in replanted sites but did not always lead to increased fruit production. Strawberry plants after a rotation of kale/sweet corn/rye or a rotation of three sequential brown mustard crops performed similarly to fumigated plots in our studies through the first fruiting year. Most cover crop rotations left the site in a better condition for planting than allowing the site to remain fallow, if for no other reason than cover-cropped sites tended to have fewer weeds. It is possible to select preplant cover crops based on site-specific biologic, physical, and chemical soil properties that will substantially improve conditions before replanting strawberries.

\section{Literature Cited}

Aldea, V., M. Negoita, and V. Morosanu. 1998. Some cultural practices and "soil sickness" in a plum orchard. Acta Hort. 477:127-130.

Black, B.L., J.J. Swartz, P. Millner, and P. Steiner. 2003. Pre-plant crop rotation and compost amendments for improving establishment of red raspberry. J. Amer. Pomol. Soc. 57:149156.

Dhingra, O.D. and J.B. Sinclair. 1995. Basic Plant Pathology Methods 2nd ed. CRC Press, Boca Raton, Fla.

Dick, R.P., D.R. Thomas, and J.J. Halvorson. 1996. Standardized methods, sampling and sample pretreatment. In: J.W. Doran, and A.J. Jones (eds.), Methods for Assessing Soil Quality, SSSA Special Publication 49 Soil Sci. Soc. Amer., Madison, Wisc. p. 107-121.

Elmer, W.H. and J.A. LaMondia. 1999. Influence of ammonium sulfate and rotation crops on strawberry black root rot. Plant Dis. 83:119123.

Fehrmann, W. 1988. Replant disease and its importance for fruit production. Acta. Hort. 233:17-19.

Fort, S.B. and D.V. Shaw. 2000. Genetic analysis of strawberry root system traits in fumigated and nonfumigated soils. Relationships among root system above-ground traits of strawberry seedlings. J. Amer. Soc. Hort. Sci. 125:324-329.

Fox, R.A. 1965. The role of biological eradication in root-disease control in replantings of Hevea brasiliensis. In: K.F. Baker and W.C. Snyder (eds.), Ecology of Soil-Sorne Plant Pathogens. University of California Press, Berkeley, Los Angeles, Calif. p. 348-362.

Hancock, J.F., P.W. Callow, S. Serce, and A.C. Shilder. 2001. Relative performance of strawberry cultivars and native hybrids on fumigated and nonfumigated soils in Michigan. Hort Science 36:136-138.

Hansen, E.M., D.D. Myrold, and P.B. Hamm. 1990. Effects of soil fumigation and cover crops on potential pathogens, microbial activity, nitrogen availability, and seedling quality in conifer nurseries. Phytopathology 80:698704.

Jagdale, G.B., B. Ball-Coelho, J. Potter, J. Brandle, and R.C. Roy. 2000. Rotation crop effects on Pratylenchus penetrans and subsequent crop yields. Can. J. Plant Sci. 80:543-549.

Jeffers, S.N. and S.B. Martin. 1986. Comparison of two media selective for Phytophthora and Pythium species. Plant Dis. 70:1038-1043.

Josephson, K.L., C.P. Gerba, and I.L. Pepper. 2000. Cultural methods. In: R.M. Maier, I.L. Pepper, and C.P. Gerba (eds.), Environmental Microbiology. Academic San Diego, Calif. p. 213233.

Ko, W.H. and F.K. Hora. 1971. A selective medium for the quantitative determination of Rhizoctonia solani in soil. Phytopathology 61:707-710

LaMondia, J.A. 1999. Influence of rotation crops on the strawberry pathogens Pratylenchus penetrans, Meloidogyne hapla, and Rhizoctonia fragariae. J. Nematol. 31:650-655.

LaMondia, J.A., W.H. Elmer, T.L. Mervosh, and R.S. Cowles. 2002. Integrated management of strawberry pests by rotation and intercropping. Crop Prot. 21:837-846.

LaMondia, J.A. and S.B. Martin. 1989. The Influence of Pratylenchus penetrans and temperature on black root rot of strawberry by binucleate Rhizoctonia spp. Plant Dis. 73:107-110.

Larson, K.D. and D.V. Shaw. 2000. Soil fumigation and runner plant production: a synthesis of four years of strawberry nursery field trials. HortScience 35:642-646.

Mai, W.F. and G.S. Abawi. 1981. Controlling replant disease of stone fruits in northeastern United States by preplant fumigation. Plant Dis. 65:859-864.

Mai, W.F., I.A. Merwin, and G.S. Abawi. 1994. Diagnosis, etiology and management of replant disorders in New York cherry and apple orchards. Acta Hort. 363:33-41.

Mazzola, M. 1998. Elucidation of the microbial complex having a causal role in the development of apple replant disease in Washington. Phytopathology 88:930-938.

Mazzola, M., D.M. Granatstein, D.C. Elfving, and K. Millinix. 2001. Suppression of specific apple root pathogens by Brassica napus seed meal amendment regardless of glucosinolate content. Phytopathology 91:673-679.

Mazzola, M., D.M. Granatstein, D.C. Elfving, K. Mullinix, and Y.H. Gu. 2002. Cultural management of microbial community structure to enhance growth of apple in replant soils. Phytopathology 92:1363-1366.

Mazzola, M. and Y.H. Gu. 2002. Wheat genotypespecific induction of soil microbial communities suppressive to disease incited by rhizoctonia solani group (AG)-5 and AG-8 Phytopathology. 92:1300-1307.

Merwin, I.A., R. Byard, T.L. Robinson, S. Carpenter, S.A. Hoying, K.A. Iungerman, and M. Fargione. 2001. Developing an integrated program for diagnosis and control of replant problems in New York apple orchards. New York Fruit Qrtly. 9:11-15.

Miller, L.G., T.L. Connell, J.R. Guidetti, and R.S. Oremland. 1997. Bacterial oxidation of methyl bromide in fumigated agricultural soils. Appl. Environ. Microbiol. 11:4346-4354.

Molot, P.M. and H. Ferriere. 1989. Susceptibility of strawberry cultivars to Rhizoctonia solani and $R$. fragariae as influenced by inoculation technique, seasonal variations and physiological condition of the plants. Acta. Hort. 265:535-539.

Nash, S.M. and W.C. Snyder. 1962. Quantitative estimations by plate counts of propagules of the bean root rot Fusarium in field soils. Phytopathology 52:567-572.

Pinkerton, J.N., K.L. Ivors, P.W. Resser, P.R. Bristow, and G.E. Windom. 2002. The use of soil solarization for the management of soilborne plant pathogens in strawberry and red raspberry production. Plant Dis. 86:645651.

Pritts, M.P. and D. Handley (eds.). 1997. Strawberry Production Guide Northeast Regional Agricultural Engineering Service, Ithaca, N.Y. $162 \mathrm{p}$.

Ramirez-Villapudua, J. and D.E. Munneckee. 1988. Effect of solar heating and soil amendments of cruciferous residues on Fusarium oxysporum f.sp. conglutinans and other organisms. Phytopathology 78:289-295.

Reynolds, L.B., J.W. Potter, and B.R. Ball-Coelho. 2000. Crop rotation with Tagetes $\mathrm{sp}$ is an alternative to chemical fumigation for control of root-lesion nematodes. Agron. J. 92:957966.

Rieger, M., G. Krewer, and P. Lewis. 2001. Solarization and chemical alternatives to methyl bromide for preplant soil treatment of strawberries. Horttechnology 11:258264.

Sances, F.V. and E.R. Ingham. 1997. Conventional and organic alternatives to methyl bromide on California strawberries. Compost Sci. Util. 5:23-37.

Savory, B.M. 1966. Specific replant diseases. Commonwealth Bureau of Horticulture and Plantation Crops, East Malling, Maidstone, Kent. CAB. No. 1.

Summers, J.R. 1999. Cover crops reduce weeds and maintain soil quality for sustainable strawberry production. Master Thesis, Iowa State Univ. 33 p.

Weller, D.M., J.M. Raaijmakers, B.B. McSpadden Gardener, and L.S. Thomashow. 2002. Microbial populations responsible for specific soil suppressiveness to plant pathogens. Annu. Rev. Phytopathol. 40:309-348.

Wilhelm, S. 1965. Pythium ultimum and the soil fumigation growth response. Phytopathology 55:1016-1020.

Wing, K.B., M.P. Pritts, and W.F. Wilcox. 1994. Strawberry black root rot: a review. Advances in Strawberry Research 13:13-19.

Wing, K.B., M.P. Pritts, and W. Wilcox. 1995 Biotic, edaphic and cultural factors associated with black root rot in New York. HortScience 30:86-90.

Yuen, G.Y., M.N. Schroth, A.R. Weinhold, and J.F. Hancock. 1991. Effects of soil fumigation with methyl bromide and chloropicrin on root health and yield in strawberry. Plant Dis. 75:416-420. 